\title{
Correction to: Berardinelli-Seip syndrome and achalasia: a shared pathomechanism?
}

\author{
Rachel J. van der Pol ${ }^{1} \cdot$ Marc A. Benninga ${ }^{1} \cdot$ Jocelyne Magré ${ }^{2,3} \cdot$ Lionel Van Maldergem $^{4} \cdot$ Joost Rotteveel $^{5}$. \\ Marjo S. van der Knaap ${ }^{6} \cdot$ Tim G. de Meij $^{7}$
}

Published online: 24 July 2020

(C) Springer-Verlag GmbH Germany, part of Springer Nature 2020

\section{Correction to: Eur J Pediatr (2015) 174:975-980 https://doi.org/10.1007/s00431-015-2556-y}

Although the patient has provided consent for publication of this case report and accompanying images, after publication of this article it has come to the authors' attention that Fig. 1 needs changes to better protect the privacy of the patient. A modified Fig. 1 is included in this Erratum. The original Fig. 1 has been removed to protect the patient's privacy.

The online version of the original article can be found at https://doi.org/ 10.1007/s00431-015-2556-y

Tim G. de Meij

t.demeij@vumc.nl; t.demeij@amsterdamumc.nl

Rachel J. van der Pol

r.j.vanderpol@amc.uva.nl; r.vanderpol@amsterdamumc.nl

Marc A. Benninga

m.a.benninga@amc.uva.nl

Jocelyne Magré

jocelyne.magre@inserm.fr

Lionel Van Maldergem

vmald@skypro.be

Joost Rotteveel

j.rotteveel@vumc.nl

Marjo S. van der Knaap

ms.vanderknaap@vumc.nl
1 Department of Pediatric Gastroenterology and Nutrition, Emma Children's Hospital AMC, Amsterdam, The Netherlands

2 INSERM UMR_S938, Université Pierre et Marie Curie, Paris, France

3 INSERM UMR_S1087, L'Institut du Thorax, Nantes, France

4 Centre de Génétique Humaine, Université de Franche-Comté, Besançon, France

5 Department of Pediatric Endocrinology, VU University Medical Center, Amsterdam, The Netherlands

6 Department of Pediatric Neurology, VU University Medical Center, Amsterdam, The Netherlands

7 Department of Pediatric Gastroenterology, VU University Medical Center, Amsterdam, The Netherlands 

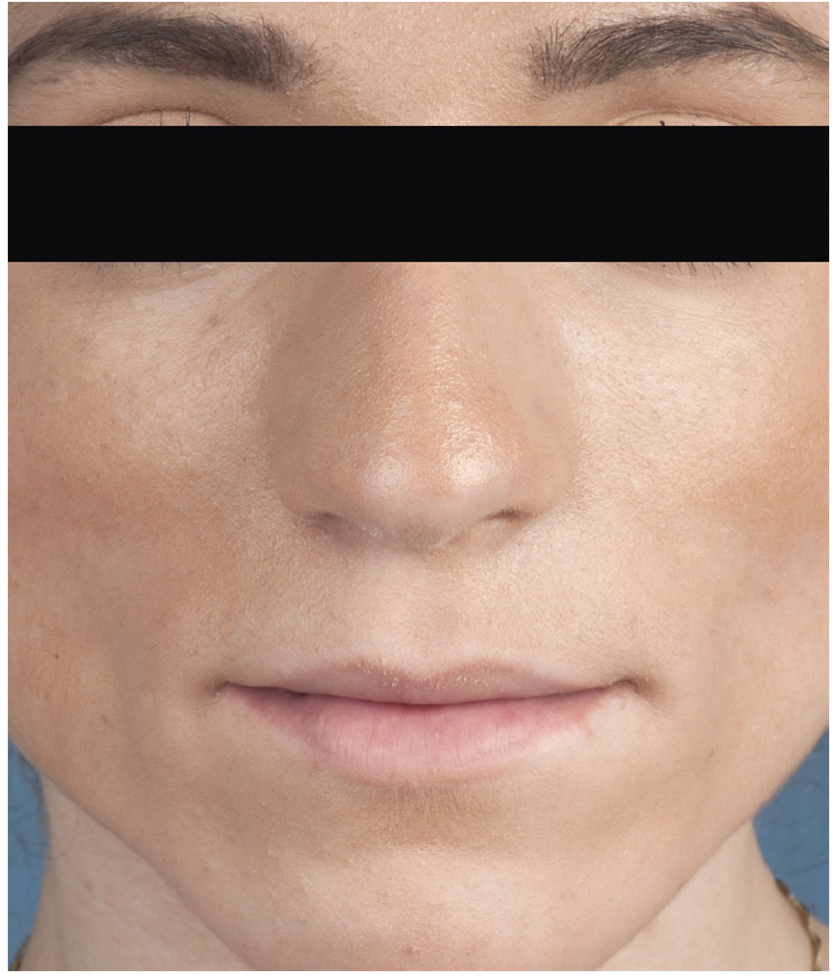

Fig. 1 Clinical picture of presented patient, demonstrating reduced subcutaneous fat tissue

Publisher's note Springer Nature remains neutral with regard to jurisdictional claims in published maps and institutional affiliations. 